\title{
Differential survival among Tahitian tree snails during a mass extinction event: persistence of the rare and fecund
}

\author{
C.S. Bick, Diarmaid Ó Foighil and Trevor Coote
}

\begin{abstract}
The deliberate introduction of the rosy wolf snail Euglandina rosea to the Society Islands in the 1970 s led to the mass extirpation of its rich Partulidae (Pilsbry, 1900) fauna, comprising approximately half of all species in this Pacific island tree snail family. On Tahiti ongoing field surveys have documented the survival of two of seven endemic species of Partula (P. hyalina and/or P. clara) in 38 valleys. E. rosea is now a potent extinction agent across Oceania and determining the factors enabling these two taxa to endure may have wide conservation import. We hypothesized that $P$. hyalina and $P$. clara have survived because they were the most abundant and/or widespread species and that they will eventually become extinct. We lack demographic data contemporaneous with predator introduction, but an early 2 oth century study by H.E. Crampton provides historical demographic data for intact Tahitian partulid populations. Crampton found that P. clara and P. hyalina, although widespread, were consistently rarer than their now-extirpated congeners, including in the 23 valleys he surveyed that retain surviving populations. Given this result, and the recent finding that $P$. clara and $P$. hyalina comprise a discrete founding lineage in Tahiti, it is plausible that some shared biological attribute(s) may have contributed to their survival. Crampton recorded the clutch sizes of thousands of gravid Tahitian partulids and found that these two taxa had higher instantaneous mean clutch sizes than did co-occurring congeners. Higher fecundities may have contributed to the survival of $P$. hyalina and $P$. clara in the valleys of Tahiti.
\end{abstract}

Keywords Differential survival, mass extinction, oceanic islands, Partulidae, Tahiti, tree snail

This paper contains supplementary material that can be found online at http://journals.cambridge.org

C.S. BiCK (Corresponding author) and DiaRmaid Ó FoIghiL, Museum of Zoology and Department of Ecology and Evolutionary Biology, University of Michigan, 1109 Geddes Ave, Ann Arbor, MI 48109-1079, USA. E-mail bickci@umich.edu

Trevor Coote, Partulid Global Species Management Programme, Papeete, Tahiti, Polynésie Française

Received 16 July 2013. Revision requested 11 November 2013.

Accepted 30 April 2014. First published online 24 October 2014.

\section{Introduction}

$\mathrm{O}$ ceanic islands represent some of the most isolated habitats on earth and their endemic biotas are characterized by small ranges and the absence of highly co-evolved defensive capabilities, such as anti-predator behaviours and morphologies (Paulay, 1994; Vermeij, 1999; Roff \& Roff, 2003; Fullard et al., 2007). Consequently, island biotas are exceptionally vulnerable to introduced continental predators (Paulay, 1994; D’Antonio \& Dudley, 1998). This is perhaps best exemplified by Guam's 'empty forest' (Redford, 1992) phenomenon, where a single introduced predator, the brown tree snake Boiga irregularis, has severely affected the endemic forest fauna (Savidge, 1987; Wiles et al., 2003; Mortensen et al., 2008), prompting extraordinary conservation interventions (Clark \& Savarie, 2012).

Another alien predator, the carnivorous rosy wolf snail Euglandina rosea, has also had an outsized impact on oceanic island endemic faunas, being implicated in the extinction of at least 134 terrestrial snail species (Régnier et al., 2009). A North American native, E. rosea stalks its gastropod prey by following their mucous trails, consuming small prey whole and larger individuals piecemeal (Gerlach, 2001; Shaheen et al., 2005; Davis-Berg, 2012). It is highly mobile and can climb trees, a detrimental characteristic for many arboreal Pacific island terrestrial snails (Kinzie, 1992; Meyer \& Cowie, 2011). Euglandina rosea was introduced to multiple Pacific island archipelagos in a misguided strategy to control outbreaks of the introduced giant African snail Lissachatina fulica, most notably to the Hawaiian Islands in 1955 (Cowie, 1998) and to the Society Islands in 1974 (Coote, 2007). It rapidly extirpated large numbers of endemic land snail species on both archipelagos, including members of the Achatinellidae in Hawaii (Hadfield et al., 1993) and Partulidae in the Society Islands (Clarke et al., 1984).

The loss of the Partulidae of the Society Islands has been of particular concern because this archipelago is home to c. $50 \%$ of partulid species diversity (Cowie, 1992). It has also been the main setting for 2oth century partulid studies, starting with the classic work of H.E. Crampton $(1916,1932)$ and continuing with decades of research by B. Clarke, J. Murray, M. Johnson and associates (Clarke \& Murray, 1969; Murray \& Clarke, 1980; Johnson et al., 1993). The collapse of Society Islands partulid populations following the introduction of E. rosea prompted the emergency establishment of off-archipelago captive populations for 15 
Society Island species (Murray et al., 1988; Tonge \& Bloxam, 1991; Pearce-Kelly et al., 1997). Until recently, only 5 of 61 endemic Society Islands partulid species were thought to persist in the wild (Coote \& Loève, 2003) but subsequent field surveys have found scattered extant populations on Raiatea, Moorea and Tahiti representing four additional species (Lee et al., 2008, 2009). Seven of these surviving taxa (Partula otaheitana, Partula hyalina, Partula clara, Partula affinis, Samoana attenuata, Samoana burchi, Samoana diaphana) occur on Tahiti, the largest and highest island in the archipelago (Coote, 2007; Lee et al., 2007a, 2009). The predominant Tahitian pattern is one of low elevation extirpation and montane persistence: partulid survivors are most common in cloud forest refuges of $>1,000 \mathrm{~m}$ altitude (Coote, 2007; Lee et al., 2007a, 2009), where predator activity is probably impaired by cooler temperatures (Gerlach, 1994, 2001). However, extensive field surveys beginning in 2004 have located small clusters of low elevation survivors in a number of Tahitian valleys (Coote, 2007), currently totalling 38 (Fig. 1; Table 1). Of Tahiti's eight species of Partula, two now dominate low elevation extant populations; i.e. 37 of the 38 valleys with known survivors were exclusively populated by $P$. clara and/or P. hyalina (Fig. 1; Table 1).

Partula hyalina and P. clara are closely-related species, distinguished by shell coloration, which together represent a discrete Tahitian founder lineage of Moorean origin (Lee et al., 2009). Their ability to endure almost 40 years of predation by E. rosea in the valleys of Tahiti is surprising because predation models predict partulid extirpation within 3 years of initial predator contact (Gerlach, 2001). We are interested in understanding what aspect(s) of their biology underlies this survival, not only for their individual conservation but because of the possible implications for the survival of the many endemic land snails across Oceania now threatened by E. rosea (Régnier et al., 2009).

The inverse relationships of population size (Pimm et al., 1988; Schoener \& Spiller, 1992) and geographical range (Payne \& Finnegan, 2007; Cardillo et al., 2008) to extinction risk have been well documented. Our initial hypothesis is therefore that $P$. hyalina and $P$. clara have survived because they were the most abundant and/or widespread species in Tahitian valleys and that they will eventually be driven to extinction by the predator. To test this, ideally we need a detailed census of Tahitian partulid populations contemporaneous with the 1974 introduction of E. rosea. Such a resource is not available but we do have access to a century-old dataset of Tahiti's intact partulid populations. During 1906-1909 Crampton (1916) surveyed and collected Tahitian valley tree snail populations, publishing a detailed account that has been lauded as 'among the finest work ever done on the evolution of land snails' (Gould, 1994). We therefore have an extensive demographic profile of intact Tahitian partulid populations with individual valley-level resolution. This allows us to calibrate present-day extant

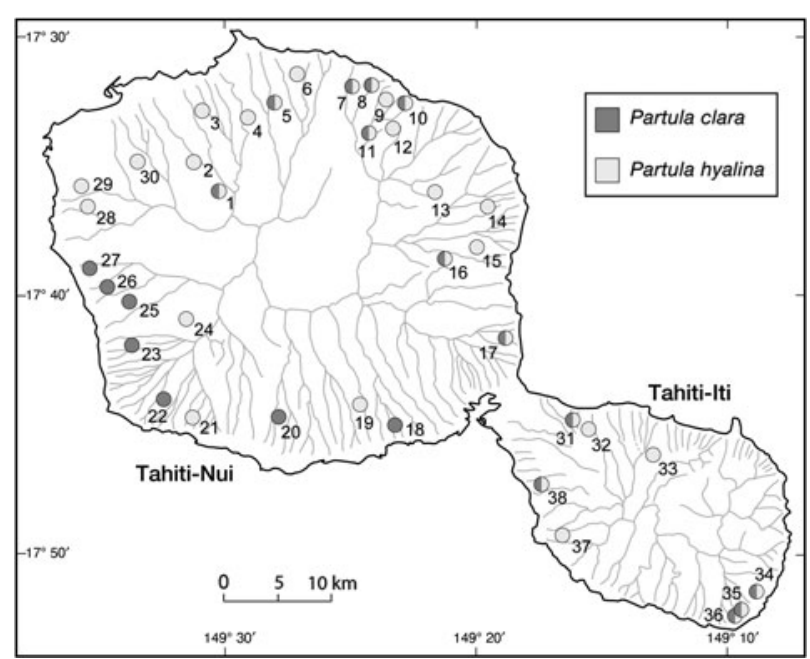

FIG. 1 Tahiti, showing the distribution of surviving low elevation partulid populations detected by Coote (2007; unpubl. data) in surveys during 2004-2010. The survivors in 37 of 38 valleys exclusively comprised Partula clara and/or Partula hyalina. A third species, Partula affinis, was found in one valley (36, Faaroa), together with $P$. clara and $P$. hyalina. See Table 1 for the names of the numbered valleys and the number of survivors.

populations with their pre E. Rosea introduction equivalents across the island as a whole, as well as for the 23 valleys Crampton surveyed that retain surviving populations (Table 1).

\section{Methods}

Crampton (1916) systematically surveyed the partulid populations of Tahiti. He divided the island of Tahiti into five subunits: Tahiti-Nui, comprising four quadrants (north, south, east and west) and the peninsula Tahiti-Iti (Taiarapu). Over four annual surveys during 1906-1909 he surveyed a large fraction of the coastal valleys present in each geographical subunit: 10 western, 20 southern, 10 northern, 10 eastern and 12 in Tahiti-Iti. Crampton (1916) did not detail his sampling methodology except to state that he walked into each valley along the primary trails during daylight hours, collecting snails from the adjacent trees and vegetation. $\mathrm{He}$ was particularly interested in population-level variation and typically obtained large sample sizes (hundreds) from each valley.

Modern-day surveys of Tahitian valleys for surviving partulids largely follow Crampton's (1916) methodology, except that the snails are much rarer and that more valleys have been surveyed (Coote, 2007). Each survey of a valley is restricted to a single day and involves walking along existing forest trails as deep as possible into the valley, stopping at regular intervals for intense searches of adjacent $5-\mathrm{m}^{2}$ patches of habitat. Where snails are encountered, all individuals within the immediate patch are enumerated within a 20-minute search period (Coote, 2007). 
TABLE 1 The 38 Tahitian valleys with surviving low elevation populations of Partula clara, Partula hyalina and Partula affinis detected by T. Coote (2007, unpubl. data) during 2004-2010 (given as number of snail populations and/or number of snails located per 20-minute search), and the species and number of snails in 23 of these 38 valleys where Crampton (1916) collected partulids during 1906-1909. The valley names used by Crampton (1916) are indicated in parentheses if they differ from the current names. See Fig. 1 for numbered locations of the valleys.

\begin{tabular}{|c|c|c|c|}
\hline \multirow[b]{2}{*}{ Valley } & \multicolumn{2}{|l|}{ Coote } & \multirow[b]{2}{*}{ Crampton's counts of adult snails per valley } \\
\hline & No. of snail populations ${ }^{1,2}$ & Snails per 20-minute search ${ }^{2}$ & \\
\hline \multicolumn{4}{|l|}{ Tahiti-Nui } \\
\hline 1, Fautaua & Several $(h y, c l)$ & & 129 (hy), 955 (otah) \\
\hline 2, Fautaua-Faaiti & 1 & $10(h y)$ & \\
\hline 3, Nahoata (Pirai) & Several $(h y)$ & & 55 (hy), 211 (filo), 988 (otah) \\
\hline 4, Tuauru & $1(h y)$ & & $14($ hy $), 374$ (aff) \\
\hline 5, Ahonu & $2(h y, c l)$ & $5(h y)$ & 5 (hy), 295 (otah) \\
\hline 6, Orofara & $1(h y)$ & & \\
\hline 7, Puhi & $2(h y, c l)$ & $2(c l)$ & \\
\hline 8, Faarapa (Farapa) & Several & $8(h y), 4(c l)$ & $9(h y), 591($ otah $)$ \\
\hline 9, Farromai (Faarumai) & 1 & $2(h y)$ & $12(h y), 1(c l), 353($ otah $)$ \\
\hline 10, Haapoponi & Several & $27(h y), 7(c l)$ & \\
\hline 11, Onohea-Faaiti & 2 & $12(h y), 17(c l)$ & \\
\hline 12, Onohea-Faarahi (Tiarei) & 1 & $3(h y)$ & $1(h y), 166($ otah $)$ \\
\hline 13, Tahaute (Mahaena) & 1 & $2(h y)$ & $2(h y), 3(c l), 147$ (otah) \\
\hline 14, Faaiti & 1 & $2(h y)$ & \\
\hline 15, Faatautia & 1 & $2(h y)$ & 12 (aff) \\
\hline 16, Vaiiha (Papeiha) & 2 & $11(h y), 2(c l)$ & $6(h y), 3(\mathrm{cl}), 273$ (otah) \\
\hline 17, Vaitoare & Several & $24(h y), 3(c l)$ & \\
\hline 18, Vaioo & 2 & $8(c l)$ & \\
\hline 19, Faurahi (Faarahi) & $1(h y)$ & & $2($ hy $), 10(\mathrm{cl}), 467$ (otah), 29 (prod) \\
\hline 20, Taapua (Taharua) & 1 & $1(c l)$ & $2(h y), 2(\mathrm{cl}), 325$ (otah) \\
\hline 21, Afererii & 1 & $1(h y)$ & \\
\hline 22, Tereia (Tereehia) & 2 & $4(c l)$ & $33(\mathrm{cl}), 130($ otah $)$ \\
\hline 23, Vaipoe (Atitara) & 2 & $10(c l)$ & $36(\mathrm{cl}), 154($ otah $)$ \\
\hline 24 , Orofero (Orofere) & Several $(h y)$ & & $2($ hy), 49 (cl), 18 (nod), 197 (otah) \\
\hline 25, Tiapa (Aoua) & 2 & $14(h y)$ & $19($ hy $), 67(\mathrm{cl}), 396($ nod $), 650$ (otah) \\
\hline 26, Papehue & 1 & $1(c l)$ & $4($ hy), 35 (cl), 210 (nod), 143 (otah) \\
\hline 27, Maruapo (Maruapoo) & 1 & $4(c l)$ & 11 (hy), 4 (cl), 795 (nod), 135 (otah) \\
\hline 28, Matatia (Taapuna) & Several & $3(h y)$ & 13 (hy), 313 (nod), 225 (otah) \\
\hline 29, Tihiute & $1(h y)$ & & \\
\hline 30, Tipaerui-Faaiti & $1(h y)$ & & $22($ hy), 937 (otah) \\
\hline \multicolumn{4}{|l|}{ Tahiti-Iti (Taiarapu) } \\
\hline 31, Rarouri & Several $(h y, c l)$ & & \\
\hline 32, Tehoro & Several $(h y)$ & 1 & $11(h y), 1(c l), 306$ (aff) \\
\hline 33, Ahaavini (Haavini) & 1 & $1(h y)$ & $20(h y), 40(\mathrm{cl}), 273$ (otah) \\
\hline 34, Vaita & Several $(h y, c l)$ & & \\
\hline 35, Taapeha & Several $(h y, c l)$ & & \\
\hline 36, Faaroa & Several (hy, cl, aff) & & \\
\hline 37, Vavi (Vavii) & $1(h y)$ & & $26(h y), 22(c l), 225$ (otah) \\
\hline 38, Faaana & $1(h y, c l)$ & & \\
\hline
\end{tabular}

${ }^{1}$ Several, $\geqslant_{2}$ remnant populations

${ }^{2}$ hy, P. hyalina; otah, P. otaheitana; filo, P. filosa; aff, P. affinis; cl, P. clara; prod, P. producta; nod, P. nodosa

At the end of each day's sampling Crampton (1916) preserved the snails for later analyses (identification, measurement, dissection) in his Columbia University laboratory. In total, Crampton (1916) collected 24,085 individuals of seven Tahitian species: P. affinis [as P. otaheitana affinis; reclassified by Kondo (1980)], P. clara, Partula filosa, P. hyalina, Partula nodosa, P. otaheitana and Partula producta. We extracted his frequency data for each valley surveyed, combining data for subspecies categories into totals for each species. Although the scale of Crampton's (1916) collecting was extraordinary by today's standards, it is unlikely to have been the main driver in their subsequent extirpation. His sampling was restricted to snails adjacent to the main valley paths and, as late as 1970, the valleys of Tahiti continued to support significant populations of partulids (John B. Burch, pers. comm.). 
Partulids are ovoviviparous hermaphrodites and adults typically contain a small number of progeny at different stages of development, giving birth to single young at multiweek intervals (Murray \& Clarke, 1966). Crampton (1916) dissected the adults he collected, recording the number of eggs, embryos and shelled young present in the reproductive tracts of individual gravid females when collected (i.e. instantaneous clutch size). He presented these data as means per valley population for five species: $P$. affinis, $P$. filosa, $P$. nodosa, $P$. otaheitana and $P$. producta. As a result of the relatively low abundance of $P$. clara and $P$. hyalina, he calculated their mean instantaneous clutch sizes over multiple valleys, grouped into his five geographical subunits.

We compiled Crampton's (1916) mean instantaneous clutch size data, combining his subspecies data into single species values for each valley/quadrant. We then calculated estimates of mean clutch sizes across the entire island for each species.

\section{Results}

Crampton (1916) calculated the relative frequency of each species he collected across Tahiti from 1906 to 1909 (Fig. 2a). Of the seven species of Partula he collected on Tahiti, P. otaheitana was the most abundant (a total of 18,955 individuals were collected) and the most widespread, being found in 51 of the 62 valleys surveyed. It was the most numerous partulid species in 48 of the 51 valleys in which it was recorded, usually comprising $>90 \%$, of all individuals collected in each valley (Supplementary Fig. S1).

Partula nodosa was the second most abundant Tahitian partulid species collected by Crampton (1916). The 1,922 specimens he collected (Fig. 2a) had a regional distribution within the island, being restricted to seven western valleys and predominating in three of them (Supplementary Fig. S1). Partula affinis was almost as numerous: 1,560 individuals (Fig. 2a) were collected from 10 valleys distributed in the northern, eastern and southern quadrants, as well as on Tahiti-Iti (Crampton, 1916). In eight of these valleys P. affinis predominated, comprising $>80 \%$ of all tree snails collected (Supplementary Fig. S1). The two rarest species collected, $P$. filosa and P. producta (Fig. 2a), were both single-valley endemics. They formed minor components of their respective valley partulid totals (P. filosa $17 \%$ and $P$. producta $6 \%$; Supplementary Fig. $\mathrm{S}_{1}$ ) and both species are now extinct.

A century ago $P$. clara and $P$. hyalina were both widespread in Tahiti, recorded from 43 and 51 of the 62 valleys surveyed, respectively (Crampton, 1916). Although they approached $P$. otaheitana's extensive range across the island of Tahiti, P. clara and P. hyalina were much rarer; the surveys yielded totals of 819 and 589 individuals, respectively (Fig. 2a). Each of these two species typically composed $<5 \%$ of the tree snails collected in individual valleys, with their highest incidence being $28 \%$ for P. clara and $21 \%$ for $P$. hyalina (Supplementary Fig. S1).

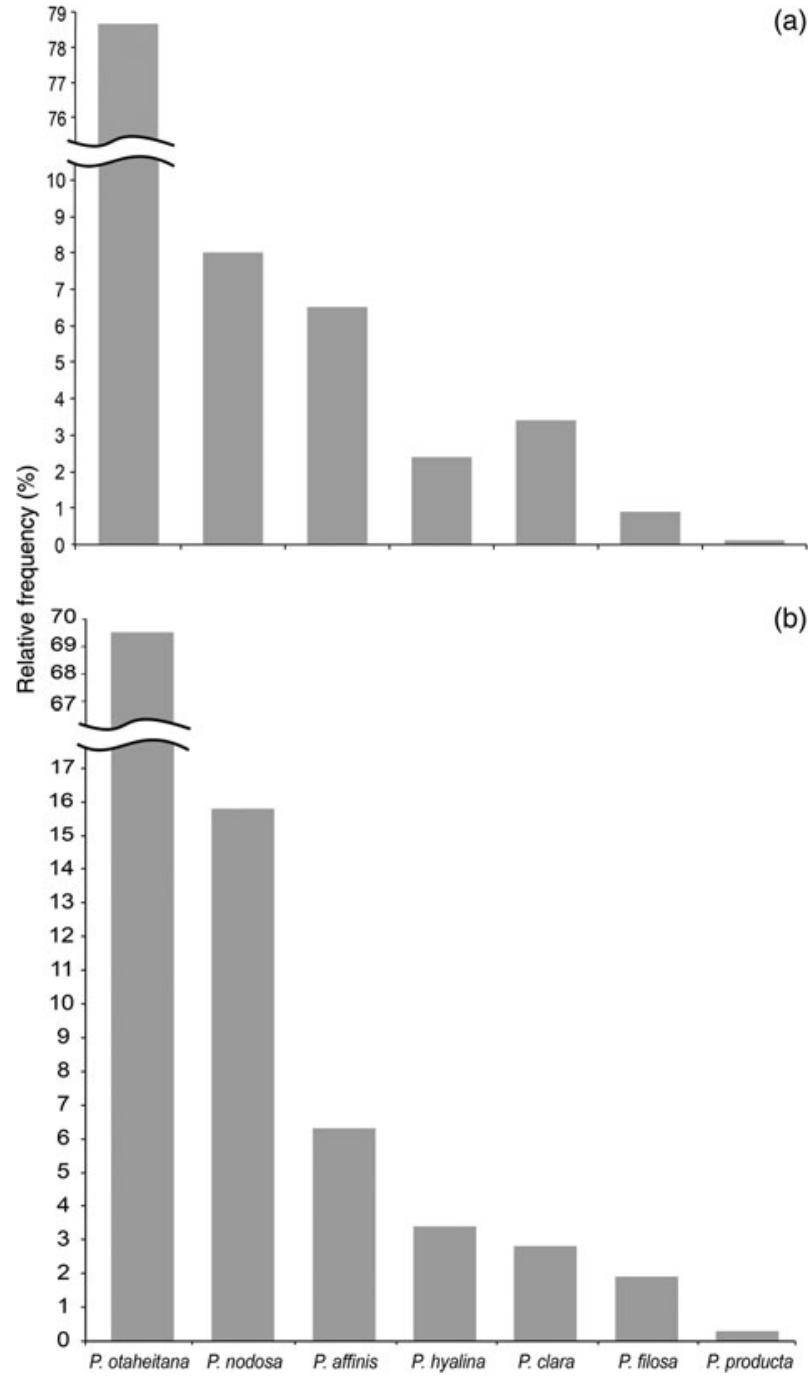

FIG. 2 The overall relative frequencies, on a logarithmic scale, of (a) seven endemic species of Tahitian Partula (P. otaheitana, $\mathrm{n}=18,955 ; P$. nodosa, $\mathrm{n}=1,922 ; P$. affinis, $\mathrm{n}=1,560 ; P$. hyalina, $\mathrm{n}=589 ;$ P. clara, $\mathrm{n}=819 ;$ P. filosa, $\mathrm{n}=211 ;$ P. producta, $\mathrm{n}=29$ ) collected by Crampton (1916) in the 62 valleys he surveyed during 1906-1909, and (b) of these seven species (P. otaheitana, $\mathrm{n}=7,631 ; P$. nodosa, $\mathrm{n}=1,732 ; P$. affinis, $\mathrm{n}=692 ; P$. hyalina, $\mathrm{n}=369 ;$ P. clara, $\mathrm{n}=306 ;$. filos $, \mathrm{n}=211, P$. producta, $\mathrm{n}=29)$ in 23 Tahitian valleys that retain recent survivors (Table 1).

Ongoing field surveys of Tahitian valleys since 2004 have encountered remnant populations of $P$. clara and/or $P$. hyalina in 38 valleys (Coote, 2007; T. Coote, unpubl. data; Fig. 1; Table 1). We cross-referenced these with the 62 valleys that Crampton surveyed in 1906-1909 and identified 23 valleys containing present-day species that were also collected by Crampton (Table 1 ). Fig. 2 b shows that, a century ago, the relative frequencies of $P$. clara and $P$. hyalina among the 23 Tahitian valleys where they survive today were not exceptional, but closely matched their relative frequencies across the island as a whole (Fig. 2a). Partula otaheitana was the most common species and P. clara and/or $P$. hyalina were minor constituents. This general pattern was 


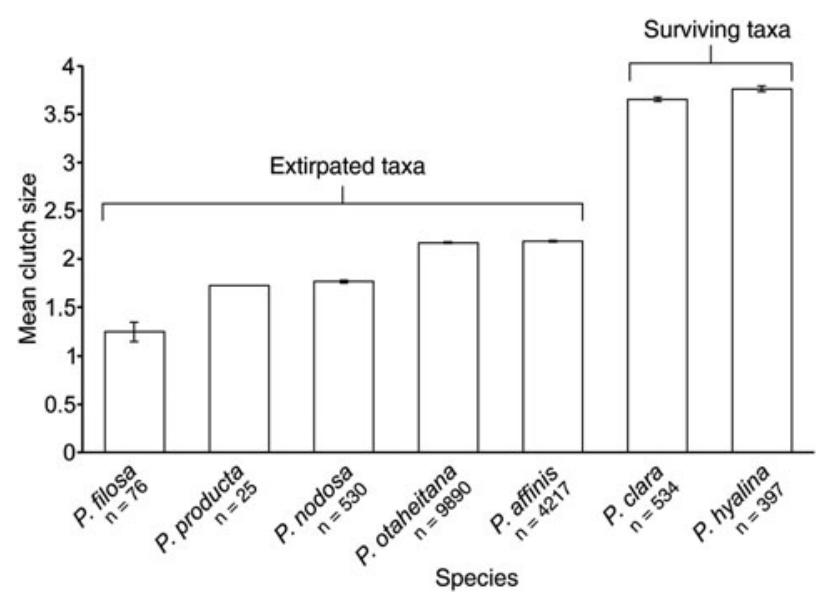

FIG. 3 Mean instantaneous clutch sizes for 15,669 gravid individuals of the seven endemic partulid species collected by Crampton (1916) across 62 Tahitian valleys during 1906-1909. Standard error bars are included for all taxa except $P$. producta (one sampling event). Partula clara and P. hyalina are labelled as surviving taxa because they dominate extant low elevation partulid populations on Tahiti (Fig. 1). The remaining five species, labelled as extirpated taxa, are absent from Tahitian valleys, with the exception of one valley population of $P$. affinis (Fig. 1).

maintained at the level of individual valleys, with the exception that $P$. otaheitana was replaced as the locally dominant species by either $P$. affinis or $P$. nodosa in a few valleys (Supplementary Fig. S1). Partula clara survives today in three valleys (Fautaua, Ahonu and Faarapa; Table 1) where it was sufficiently rare a century ago to go undetected by Crampton, despite his intensive collecting (e.g. his Fautaua Valley sample size was 1,084 snails). Given the very low migration rates of partulid tree snails (e.g. 1-10 m per year; Murray \& Clarke, 1984), we consider it likely that these three valley populations of $P$. clara represent local survivors rather than de novo colonists from other valleys. The formerly locally dominant species in these three valleys, $P$. otaheitana, has been extirpated, despite having been at least 2-3 orders of magnitude more common than the surviving P. clara.

Fig. 3 is a summary of Crampton's (1916) mean instantaneous clutch sizes for Tahitian valley partulids. The surviving taxa, P. clara and P. hyalina, had markedly higher clutch sizes than their now-extirpated congeners.

\section{Discussion}

The introduction of E. rosea to Tahiti in 1974 exposed naïve endemic tree snails to an uncontrolled predator-prey experiment in which each valley population represented a discrete iteration. Outcomes in 37 of 38 valleys with known survivors have been strikingly uniform: persistence of two of seven endemic Tahitian species of Partula: P. clara and/or P. hyalina (Fig. 1; Table 1). Our initial hypothesis, that the surviving taxa endured because they were the most abundant and/or widespread species, is clearly refuted by Crampton's (1916) data. A century ago these two species were relatively rare, typically representing $<5 \%$ of the original species diversity in most valleys, including those valleys where they still persist (Fig. 2b; Table 1). Although P. hyalina and P. clara were widely distributed, this cannot explain their survival relative to the widespread, co-occurring and much more abundant $P$. otaheitana, now completely extirpated from the valleys of Tahiti (Coote, 2007; Fig. 1).

Molecular phylogenies have shown that $P$. clara and $P$. hyalina are two colour morphs of a founding lineage that is distinct from other Tahitian congeners (Lee et al., $2007 \mathrm{~b}, 2009)$. It is therefore plausible that some shared phylogenetic trait has contributed to their differential survival. One such potential trait is evident in Crampton's (1916) dataset: P. clara and P. hyalina exhibited similar instantaneous clutch sizes that were markedly higher than those of their extinct congeners (Fig. 3). These data raise an obvious paradox regarding the population structure of tree snails in Tahitian valleys in 1906-1909. If mean clutch sizes in $P$. clara and $P$. hyalina were so much higher, why were they so rare relative to three of their congeners, especially $P$. otaheitana? This discrepancy implies that, a century ago, P. clara and P. hyalina were inferior competitors to their now-extirpated Tahitian valley congeners.

Species with a low intrinsic rate of increase, as a result of factors such as low fecundity, are at increased risk of extinction from stochastic events (Beissinger, 2000). Island endemics with greater reproductive effort are therefore predicted to have a higher likelihood of surviving the introduction of non-native predators. In the Guam avifauna, for example, species with larger clutch sizes have exhibited better survival (Wiles et al., 2003). Introduction of the alien predator $E$. rosea to the Society Islands affected the population dynamics of local partulids by increasing their mortality rates (Clarke et al., 1984). The significantly higher instantaneous clutch sizes of $P$. clara and $P$. hyalina relative to their extirpated congeners (Fig. 3) may be a major factor contributing to their continued survival in Tahitian valleys.

However, there are inherent shortcomings in Crampton's (1916) data that complicate the comparison of reproductive rate among Tahitian partulids. Instantaneous clutch size estimates were compiled from diverse valleys and individual valley-level clutch size estimates are not available for the two surviving taxa, making within-valley comparisons of survivors and non-survivors impossible. In addition, the exact gestation period is unknown for individual Tahitian species. We cannot at present rule out the possibility of longer gestation periods in $P$. clara and $P$. hyalina than in the extirpated species, a developmental pattern that could yield higher instantaneous clutch sizes (Fig. 3) but not necessarily higher birth rates.

The impact of introduced predators may vary across island microhabitats; e.g. in addition to larger clutch sizes, survival in the Guam avifauna is associated with the ability to nest in locations inaccessible to the brown tree snake 
(Wiles et al., 2003). On Tahiti more low elevation sites with known survivors (Fig. 1; Table 1) contain P. hyalina (31 of 38 ) than P. clara (20 of 38 ) and this outcome may reflect microhabitat differences among the two taxa. Crampton (1916) noted a discrete distributional trait of $P$. hyalina that distinguished it from its Tahitian congeners. In addition to occurring in dense forest (the typical partulid habitat) he regularly observed $P$. hyalina at forest edges and in clearings where it was exposed to prolonged direct sunlight. P. hyalina has a distinctively white shell, and a correlation between light shell coloration and an enhanced ability to withstand exposure to direct sunlight is well known among land snail species (Jones, 1973, 1982; Hazel \& Johnson, 1990; Ozgo, 2011). If E. rosea has a lower tolerance of direct sunlight, it is possible that this microhabitat distinction plays an additive role in the survival of $P$. hyalina.

The persistence of two of seven species of endemic Tahitian Partula under selection pressure from an introduced continental predator has some parallels with the fate of Guam's avifauna (Wiles et al., 2003). In both cases endemic species with larger clutch sizes exhibited better survival, being able to persist in the presence of the predator for multiple decades (40 years on Tahiti, 60-70 years on Guam). We suspect that this general pattern may also apply to diverse clades of endemic taxa across Oceania. If so, this could guide the prioritization of limited conservation resources for the preservation of Pacific island species that are threatened with extinction. For example, when a novel introduced predator appears on an island, it may be appropriate to give the highest conservation priority to endemic prey species that have lower reproductive potential.

\section{Acknowledgements}

The constructive comments of two anonymous reviewers significantly improved this article. This work was funded by grants from the University of Michigan International Institute Individual Fellowship and the Department of Ecology and Evolutionary Biology to CSB and by National Science Foundation award OCE 0850625 and National Geographic award 9180-12 to DÓF.

\section{References}

BeIsSinger, S.R. (2000) Ecological mechanisms of extinction. Proceedings of the National Academy of Science, 97, 11688-11689.

Cardillo, M., Mace, G.M., Git tleman, J.L., Jones, K.E., Bielby, J. \& Purvis, A. (2008) The predictability of extinction: biological and external correlates of decline in mammals. Proceedings of the Royal Society of London B, 275, 1441-1448.

CLARK, L. \& SAVARIE, P.J. (2012) Efficacy of aerial broadcast baiting in reducing brown treesnake numbers. Human-Wildlife Interactions, $6,212-221$.
Clarke, B. \& Murray, J. (1969) Ecological genetics and speciation in land snails of the genus Partula. Biological Journal of the Linnaean Society, 1, 31-42.

Clarke, B., Murray, J. \& Johnson, M.S. (1984) The extinction of endemic species by a program of biological control. Pacific Science, $38,97-104$.

Coоте, T. (2007) Partulids on Tahiti: differential persistence of a minority of endemic taxa among relict populations. American Malacological Bulletin, 22, 83-87.

Coote, T. \& Lò̀ve, E. (2003) From 61 species to five: endemic tree snails of the Society Islands fall prey to an ill-judged biological control programme. Oryx, 37, 91-96.

Cowie, R.H. (1992) Evolution and extinction of Partulidae, endemic Pacific island land snails. Philosophical Transactions of the Royal Society of London B, 335, 167-191.

Cowie, R.H. (1998) Patterns of introduction of non-indigenous non-marine snails and slugs in the Hawaiian Islands. Biodiversity and Conservation, 7, 349-368.

Crampton, H.E. (1916) Studies on the variation, distribution, and evolution of the genus Partula. The species inhabiting Tahiti. Carnegie Institute of Washington Publication, 228, 1-311.

Crampton, H.E. (1932) Studies on the variation, distribution, and evolution of the genus Partula. The species inhabiting Moorea. Carnegie Institute of Washington Publication, 410, 1-336.

D’Antonio, C.M. \& Dudley, T.L. (1998) Biological invasions as agents of change on islands versus mainlands. In Islands: Biological Diversity and Ecosystem Function (eds P.M. Vitousek, L.L. Loope \& H. Adsersen), pp. 103-121. Springer, Berlin, Germany.

Davis-Berg, E. (2012) The predatory snail Euglandina rosea successfully follows mucous trails of both native and non-native prey snails. Invertebrate Biology, 131, 1-10.

Fullard, J.H., Ratcliffe, J.M. \& ter Hofstede, H.M. (2007) Neural evolution in the bat-free habitat of Tahiti: partial regression in an anti-predator auditory system. Biology Letters, 3, 26-28.

GerLACH, J. (1994) The ecology and behaviour of Euglandina rosea. $\mathrm{PhD}$ thesis. Oxford University, Oxford, UK.

Gerlach, J. (2001) Predator, prey and pathogen interactions in introduced snail populations. Animal Conservation, 4, 203-209.

Gould, S.J. (1994) Eight Little Piggies: Reflections in Natural History. W.W. Norton \& Company, New York, USA.

Hadfield, M.G., Miller, S.E. \& CAR Wile, A.H. (1993) The decimation of endemic Hawaiian tree snails by alien predators. American Zoologist, 33, 610-622.

Hazel, W.N. \& Johnson, M.S. (1990) Microhabitat choice and polymorphism in the land snail Theba pisana (Müller). Heredity, 65, 449-454.

Johnson, M.S., Murray, J. \& Clarke, B. (1993) The ecological genetics and adaptive radiation of Partula on Moorea. Oxford Surveys in Evolutionary Biology, 9, 167-236.

JONES, J.S. (1973) Ecological genetics and natural selection in molluscs. Science, 182, 546-552.

Jones, J.S. (1982) Genetic differences in individual behaviour associated with shell polymorphism in the snail Cepaea nemoralis. Nature, 298, 749-750.

KinZie, R.A. (1992) Predation by the introduced carnivorous snail Euglandina rosea (Férussac) on endemic aquatic lymnaeid snails in Hawaii. Biological Conservation, 6o, 149-155.

Kondo, Y. (1980) Samoana jackieburchi, new species (Gastropoda: Pulmonata: Partulidae). Malacological Review, 13, 25-32.

Lee, T., Burch, J.B., Coote, T., Fontaine, B., Gargominy, O., Pearce-Kelly, P. \& Ó Foighil, D. (2007b) Prehistoric inter-archipelago trading of Polynesian tree snails leaves a conservation legacy. Proceedings of the Royal Society B, 272, 2907-2914. 
Lee, T., Burch, J.B., Coote, T., Pearce-Kelly, P., Hickman, C., Meyer, J.Y. \& Ó Foighil, D. (2009) Moorean tree snail survival revisited: a multi-island genealogical perspective. BMC Evolutionary Biology, 9, 204.

Lee, T., Burch, J.B., Jung, Y., Coote, T., Pearce-Kelly, P. \& Ó Forghil, D. (2007a) Tahitian tree snail mitochondrial clades survived recent mass extirpation. Current Biology, 17, R502-R503.

Lee, T., Meyer, J.Y., Burch, J.B., Pearce-Kelly, P. \& Ó Foighil, D. (2008) Not completely lost: two partulid tree snail species persist on the highest peak of Raiatea, French Polynesia. Oryx, 42, 615-619.

Meyer, W.M. \& Cowie, R.H. (2011) Distribution, movement, and microhabitat use of the introduced predatory snail Euglandina rosea in Hawaii: implications for management. Invertebrate Biology, 130, 325-333.

Mortensen, H.S., Dupont, Y.L. \& Olesen, J.M. (2008) A snake in paradise: disturbance of plant reproduction following extirpation of bird flower-visitors on Guam. Biological Conservation, 141, 2146-2154.

Murray, J. \& Clarke, B. (1966) The inheritance of polymorphic shell characters in Partula (Gastropoda). Genetics, 54, 1261-1277.

Murray, J. \& Clarke, B. (1980) The genus Partula on Moorea: speciation in progress. Proceedings of the Royal Society B, 211, 83-117.

Murray, J. \& Clarke, B. (1984) Movement and gene flow in Partula taeniata. Malacologia, 25, 343-348.

Murray, J., Murray, E., Johnson, M.S. \& Clarke, B. (1988) The extinction of Partula on Moorea. Pacific Science, 42, 150-153.

OzGo, M. (2011) Rapid evolution in unstable habitats: a success story of the polymorphic land snail Cepaea nemoralis (Gastropoda: Pulmonata). Biological Journal of the Linnean Society, 102, 251-262.

PAULAY, G. (1994) Biodiversity on oceanic islands: its origin and extinction. American Zoologist, 34, 134-144.

Payne, J.L. \& Finnegan, S. (2007) The effect of geographic range on extinction risk during background and mass extinction. Proceedings of the National Academy of Science, 104, 10506-10511.

Pearce-Kelly, P., Clarke, D., Walker, C. \& Atkin, P. (1997) A conservation programme for the partulid tree snails of the Pacific region. Memoirs of the National Museum of Victoria, 56, 431-433.

Pimm, S.L., Jones, H.L. \& Diamond, J. (1988) On the risk of extinction. American Naturalist, 132, 757-785.
RedFord, K.H. (1992) The empty forest. BioScience, 42, 412-422. Régnier, C., Fontaine, B. \& Bouchet, P. (2009) Not knowing, not recording, not listing: numerous unnoticed mollusk extinctions. Conservation Biology, 23, 1214-1221.

Roff, D.A. \& RofF, R.J. (2003) Of rats and Maoris: a novel method for the analysis of patterns of extinction in the New Zealand avifauna before human contact. Evolutionary Ecology Research, 5, 759-779.

SAVIDGE, J.A. (1987) Extinction of an island forest avifauna by an introduced snake. Ecology, 68, 66o-668.

Schoener, T.W. \& Spiller, D.A. (1992) Is extinction rate related to temporal variability in population size? An empirical answer for orb spiders. The American Naturalist, 139, 1176-1207.

Shaheen, N., Patel, K., Patel, P., Moore, M. \& Harrington, M. A. (2005) A predatory snail distinguishes between conspecific and heterospecific snails and trails based on chemical cues in slime. Animal Behaviour, 70, 1067-1077.

Tonge, S. \& Bloxam, Q. (1991) A review of the captive-breeding programme for Polynesian tree snails Partula spp.. International Zoo Yearbook, 30, 51-59.

Vermeij, G.J. (1999) Inequality and the directionality of history. The American Naturalist, 153, 243-253.

Wiles, G.J., BART, J., BeCK, JR, R.E. \& AGUON, C.F. (2003) Impacts of the brown tree snake: patterns of decline and species persistence in Guam's avifauna. Conservation Biology, 17, 1350-1360.

\section{Biographical sketches}

C.S. BICK is interested in the ecology and evolution of endemic species and the use of evidence-based conservation to manage the impacts of invasive species on South Pacific oceanic islands effectively. DI A R M A ID Ó FoIghil focuses on molluscan evolution and systematics and has collaborated on a variety of research projects involving terrestrial molluscs. Trevor Coоte has been the principal field biologist involved in the conservation of endemic snails in French Polynesia for more than 15 years, working in collaboration with local Polynesians and government agencies as well as biologists interested in conservation on South Pacific islands. 